\title{
Hubungan Kemandirian Belajar dengan Hasil Belajar pada Matakuliah Matematika-II
}

\author{
Nurdiana Siregar $^{1^{*}}$, Nurkhairunnisa Siregar ${ }^{2}$ \\ ${ }^{1}$ Program Studi PGMI di Universitas Islam Negeri Sumatera Utara \\ ${ }^{2}$ Program Studi PGSD di Universitas Nahdatul Ulama Sumatera Utara \\ ${ }^{1}$ nurdiana.siregar282@gmail.com \\ nurkhairunnisa19@yahoo.co.id
}

\begin{abstract}
The purpose of this study was to look at the relation between self-regulated learning and learning outcomes of PGMI study program students at UIN North Sumatra. This type of research is quantitative research using the correlational method. 42 students of PGMI study program were used as samples in this study. Data collection was done using a questionnaire and a list of grades Mathematics-II students (Geometry and Measurement). Based on the results of the pearson correlation test output obtained that there is a significant relation of self-regulated learning with student learning outcomes in Mathematics-II subjects. Furthermore, to see the strength or closeness of the correlation between the two variables can be taken a decision from the Pearson Correlation value of 0.793 is in the interpretation of the $r$ value is strongly correlated, then the closeness or strength of the relationship between the two variables is categorized strong. Thus there is a strong positive correlation between self-regulated learning variables with learning outcomes of Mathematics-II subjects. Such a relationship can be interpreted that the higher the level of learning independence, the higher the achievement of student learning outcomes tends to be.
\end{abstract}

Keywords: learning; self-regulated learning; learning outcome; mathematics; geometry

\begin{abstract}
Abstrak
Tujuan penelitian ini adalah untuk melihat hubungan antara kemandirian belajar dengan hasil belajar mahasiswa program studi PGMI di UIN Sumatera Utara. Jenis penelitian termasuk penelitian kuntitatif dengan memakai metode korelasional. Mahasiswa program studi PGMI yang berjumlah 42 orang dijadikan sebagai sampel dalam penelitian ini. Pengumpulan data dilakukan dengan memakai angket dan daftar nilai mahasiswa matakuliah Matematika-II (Geometri dan Pengukuran). Berdasarkan hasil output uji korelasi Pearson diperoleh bahwa terdapat hubungan yang signifikan antara kemandirian belajar dengan hasil belajar mahasiswa matakuliah Matematika-II. Selanjutnya untuk melihat kekuatan ataupun keeratan hubungan antara kedua variabel dapat diambil keputusan dari nilai Pearson Correlation sebesar 0,793 berada pada interpretasi nilai $r$ berkorelasi kuat, maka taraf keeratan ataupun kekuatan hubungan kedua variabel dikategorikan kuat. Dengan demikian terdapat hubungan kuat ke arah positif antara variabel kemandirian belajar dengan hasil belajar matakuliah Matematika-II. Hubungan yang demikian dapat ditafsirkan bahwa semakin tinggi kadar kemandirian belajar maka cenderung makin tinggi pula pencapaian hasil belajar mahasiswa.
\end{abstract}

Kata Kunci: belajar; kemandirian belajar; hasil belajar; matematika; geometri

\footnotetext{
*Correspondence:

Email: nurdiana.siregar282@gmail.com
} 


\section{PENDAHULUAN}

Teknologi dan ilmu pengetahuan berkembang dengan cepat yang menjadikan meningkat pula persaingan diantara negara maju dan berkembang, sehingga menuntut terciptanya generasi penerus bangsa yang unggul. Generasi penerus unggul terbentuk dari kegiatan pendidikan formal dan nonformal. Manusia unggul itu terbentuk apabila para peserta didik dalam belajar tidak hanya ketika di sekolah tetapi memanfaatkan waktu untuk belajar ketika di luar sekolah. Sistem kredit semester di Perguruan Tinggi (PT) juga menerapkan waktu belajar tidak hanya tatap muka, tetapi ada tugas dan praktik. Oleh karena itu dalam mendukung sistem SKS mengharuskan mahasiswa untuk memiliki sikap kemandirian dalam belajar.

Kemandirian belajar mahasiswa diperlukan dalam menunjang pencapaian kompetensi mahasiswa semasa proses pendidikan di PT. Kemandirian belajar berupa mencari referensi ataupun bahan kuliah yang lebih beragam dan menggali lebih dalam ilmu yang hendak dicapai. Hal tesebut disebabkan kemandirian belajar mahasiswa memiliki peran penting dan menjadi salah satu aspek yang mempengaruhi kesuksesan studinya dalam memperoleh ilmu khususnya belajar ilmu matematika. Sejalan dengan (Cheng, 2011:12) bahwa kemandirian belajar siswa adalah kontribusi yang paling signifikan untuk keberhasilan belajar siswa.

Kemandirian belajar menurut (Pange, 2014:170) adalah proses kombinasi dimana siswa memantau dan mengendalikan kinerja belajarnya untuk mencapai hasil yang diinginkan dan merupakan proses bertindak sesuai keinginan mereka sendiri. Hal tersebut dipertegas oleh (Alotaibi, Tohmaz, and Jabak 2017:30) menyatakan bahwa inti dari konsep kemandirian belajar ini bergantung pada kemampuan siswa untuk mandiri dalam komponen kognitif, motivasional, dan kontekstual seperti penetapan tujuan, observasi, penilaian dan reaksi pada tingkat penyempurnaan diri demi mencapai tujuan pendidikan mereka. Pernyataan tersebut berarti sikap dewasa dalam belajar merupakan bagian integral dari kemandirian belajar.

Self-Regulated Learning atau dalam bahasa Indonesianya disebut kemandirian belajar memiliki peran penting bagi mahasiswa agar dapat menghadapi permasalahan yang muncul dari dalam kelas maupun dari lingkungan masyarakat yang tantangannya tentu lebih rumit. Manfaat lain dari kemandirian belajar ini juga menurunkan tingkat ketergantungan kepada orang lain dalam kehidupan sehari-hari. Selain itu, pentingnya kemandirian belajar sangat berpengaruh pada kemampuan seseorang memanajemen dirinya sendiri, kemudian dia mengetahui kelebihan dan kekurangan dirinya, dia mengetahui model pembelajaran atau strategi belajar seperti apa yang dirasa lebih nyaman dan paling cocok untuk dirinya. 
Mengingat begitu pentingnya kemandirian belajar harus ada pada pembelajar, maka para akademisi seperti guru maupun pihak-pihak yang terkait dalam dunia pendidikan wajib memberikan perhatian besar untuk menanamkan kemandirian belajar bagi para peserta didik. Bagi seorang pelajar jika ia yang sudah memiliki sifat self-regulated learning pasti terbiasa mandiri dan mampu mengatur belajarnya serta memiliki ide yang gamblang tentang mengapa dan bagaimana dan strategi pengaturan diri sendiri seperti apa yang spesifik harus dilakukan. Pada umumnya mereka adalah peserta didik yang dinamis dalam hal metakognisi, pemecahan masalah, motivasi, disiplin dan mampu mengendalikan tindakannya. Sebagai contoh, mereka berfokus pada peningkatan potensi belajar mereka, menggunakan strategi sendiri, menilai hasil pencapaiannya dan memperbaiki pembelajaran mereka sendiri berdasarkan hasil yang diperolehnya itu. Akibatnya, peserta didik tidak mudah goyah atas pengaruh orang lain karena mereka mampu megontrol perasaan mereka sendiri terhadap strategi atau pembelajaran (Çam, S. S., and Oruç, 2014:2).

Melatih mahasiswa untuk menjadi pembelajar yang mandiri secara efektif dapat membantu mereka memperoleh keterampilan dalam memanajemen pengetahuan dasar secara mendalam dan bermakna, yang terpenting bagaimana caranya untuk menciptakan, mengelola, dan mempertahankan lingkungan belajar pribadi yang dirasa pembelajar lebih nyaman. Pada akhirnya, seorang pelajar yang mandiri akan terus menyesuaikan strategi yang digunakannya untuk menggunakan alat atau media untuk mengoptimalkan lingkungan belajar pribadi dan untuk memperoleh sikap kemandirian belajar secara efektif dari pengalaman belajar demi menggapai hasil yang diinginkan (Dabbagh, N., and Kitsantas, 2012:6).

Ada tiga faktor yang dijelaskan oleh Woolfolk yang tentu memiliki keterkaitan dengan kemandirian belajar peserta didik yaitu: pengetahuan (knowledge), motivasi (Motivation), dan pribadi yang disiplin (self-dicipline). Maksudnya adalah supaya peserta didik memperoleh sifat kemandirian dalam belajarnya tentu sudah suatu keharusan bagi mereka wajib memiliki pengetahuan perihal materi pelajaran yang akan dipelajari dan mempunyai pemahaman tentang dirinya sendiri. Kemudian selain dari pengetahuan, motivasi juga mempengaruhi kemandirian belajar karena mereka yang memiliki motivasi akan bersemangat untuk menyelesaikan berbagai tugas yang diberikan dengan senang hati. Orang yang mempunyai sifat disiplin yang tinggi sudah pasti memiliki kemandirian belajar yang baik pula (Qohar, A., 2013:64)

Terlepas dari faktor-faktor diatas, ada indikator yang menjadi acuan pengukuran kemandirian belajar peserta didik. Adapun indikator dalam menilai tingkat kemandirian belajar mahasiswa pada penelitian ini dimodifikasi dari pendapat (Sumarmo, 2004) yaitu: 1) memiliki usaha dalam belajar, 2) mampu memeriksa kebutuhan belajarnya, 3) bisa menentukan sasaran dan tujuan belajarnya, 4) memantau, mengatur dan memeriksa kemajuan belajar, 5) 
menganggap kesulitan sebagai tantangan, 6) pandai menggunakan dan mendapatkan sumber lain yang relevan, dan 7) mengevaluasi proses belajar dan hasil belajar yang diperoleh.

Sebenarnya sikap kemandirian mahasiswa dalam belajar memegang peran yang cukup penting sehingga penanaman dan pengembangan sifat tersebut pada diri mahasiswa merupakan suatu keniscayaan untuk mencapai hasil belajar yang baik demi kemandiriannya dimasa depan. Sebab, seseorang yang didalam dirinya memiliki sikap kemandirian dalam suatu hal sudah pasti akan berdampak positif untuk dirinya sendiri. Dengan demikian, jika kemandirian belajar mahasiswa meningkat maka mahasiswa akan memperoleh keberhasilan dalam pendidikannya.

Pernyataan diatas sejalan dengan penelitian (Muhammad, A. S., \& Abu Bakar, 2015), dimana mereka meneliti hubungan atau keterkaitan antara kemandirian belajar dengan prestasi akademik mahasiswa UNISZA di Malaysia. Hasil yang diperoleh dari penelitian tersebut dijelaskan bahwa ada hubungan ataupun keterkaitan yang begitu kuat antara kemandirian belajar dengan prestasi akademik, dan kemandirian belajar bisa berfungsi sebagai prediktor yang baik untuk meramal prestasi akademik (IPK) siapa yang lebih tinggi.

Pelajar yang memiliki sikap kemandirian belajar yang tinggi pasti memiliki prestasi tinggi juga, dan sebaliknya pelajar dengan kemandirian belajar rendah akan berprestasi rendah. Selain prestasi belajar, mengatur kemandirian belajar juga terbukti mampu meningkatkan motivasi dan kepercayaan diri pelajar sehingga dengan peningkatan motivasi dan kepercayaan diri pelajar dalam belajar akan lebih aktif untuk mendapatkan hasil belajar yang baik. Oleh karena itu, untuk pencapaian prestasi belajar yang tinggi, penggunaan kemandirian belajar dalam mengatur strategi pembelajaran harus sangat dipertimbangkan (Fauzi, A., and Widjajanti, 2018:5).

Keberhasilan dalam bidang akademis bisa diamati dari perolehan hasil belajar peserta didik. Arti singkat dari hasil belajar yaitu keterampilan ataupun keahlian yang telah dimiliki peserta didik sesudah ia mendapatkan pengetahuan dari pengalaman belajar (Sudjana, 2009:22). Faktor keberhasilan suatu kegiatan belajar diantaranya dapat dilihat dari hasil belajar mahasiswa dalam bentuk hasil ujian, pergantian tingkah laku ataupun sikap ke arah yang lebih baik, dan itulah yang dimaksud dengan taksonomi (taxonomy) didalamnya meliputi tiga aspek yaitu aspek kognitif, afektif, dan psikomotorik (Arikunto, 2005:115). Hasil belajar yang terkandung dalam taksonomi ini sampai sekarang masih sangat penting dan tetap menjadi patokan untuk mengukur kompetensi peserta didik.

Mata kuliah Matematika-II di MI/SD (lingkup Geometri dan Pengukuran) termasuk dalam kelompok matakuliah wajib untuk mahasiswa yang mengambil program studi Pendidikan Guru Madrasah Ibtidaiyah atau yang lebih dikenal dengan singkatan PGMI yang disesuaikan dengan peraturan kurikulum 
pendidikan tinggi. Mata kuliah Matematika-II di MI/SD ini adalah pendalaman pelajaran matematika yang bertujuan untuk mempersiapkan calon guru madrasah ibtidaiyah agar mahir menyampaikan dan menanamkan ilmu dasar matematika pada siswa khususnya pada bidang Geometri dan Pengukuran.

Jika ditemukan hasil belajar mahasiswa pada mata kuliah Matematika-II masih dibawah standar, maka akan mendatangkan akibat buruk pada kompetensi lulusan yang dihasilkan. Oleh sebab itu perlu dicermati hal-hal apa saja yang menunjang pencapaian hasil belajar. Dalam pencapaian hasil belajar sudah tentu ditularkan oleh faktor eksternal dan juga faktor internal dari mahasiswa itu sendiri. Adapun faktor eksternal berasal dari lingkungan keluarga, masyarakat dan sekolah. Sedangkan faktor internal yang menghabat hasil belajar peserta didik antara lain sikap pesimis, minat, bakat, kurang mampu memanfaatkan waktu luang dengan baik, tidak kreatif, lemah memotivasi diri, kecerdasan, rasa malas belajar dirumah, dan tidak mampu memanajemen waktu karena kurang disiplin dalam belajar baik dirumah maupun dikampus. Hambatan tersebut termasuk dalam indikator kemandirian belajar yang tidak dimiliki mahasiswa.

Berdasarkan penjelasan diatas, secara tidak langsung kemandirian belajar dijadikan sebagai bagian dari faktor internal yang ikut memberikan kontribusi besar dalam penggapai hasil belajar yang baik. Selain itu, kemandirian belajar juga merupakan bidang penelitian yang tergolong cukup penting dalam pembelajaran dan pengajaran di perguruan tinggi dan mendapat perhatian lebih besar dalam penelitian pendidikan tinggi (Pintrich, 1995). Berdasarkan latar belakang tersebut, maka rumusan masalah yang hendak dikaji pada riset ini yaitu apakah terdapat hubungan yang signifikan antara kemandirian belajar dengan hasil belajar mahasiswa prodi PGMI pada matakuliah Matematika-II di MI/SD (Geometri dan Pengukuran).

\section{METODE PENELITIAN}

Jenis penelitian menggunakan penelitian kuntitatif yaitu metode korelasional. Analisis korelasi untuk melihat ada atau tidaknya hubungan antara kemandirian belajar (variabel X) dengan hasil belajar mahasiswa pada matakuliah Matematika-II (variabel Y). Adapun populasi dalam penelitian ini adalah semua mahasiswa UINSU yang mengambil program Studi S1 PGMI pada semester IV yang berjumlah 217 orang. Sampel diperoleh setelah dilakukan teknik cluster random sampling yaitu dengan cara memberikan penomoran pada kertas-kertas kecil yang memuat nama kelas, kemudian digulung dan diundi sehingga akhirnya diperoleh satu gulungan kertas, yang terpilih dari kegiatan tersebut adalah mahasiswa kelas PGMI-4 semester IV yang berjumlah 42 orang.

Instrumen pengumpulan data yang dipakai adalah angket dan dokumentasi. Penggunaan angket difungsikan untuk memperoleh data variabel $\mathrm{X}$ yaitu data 
kemandirian belajar yang mencakup 32 pernyataan dengan berpatokan pada 7 indikator dalam proses penilaiannya menggunakan skala likert. Angket kemandirian belajar tersebut sebelum digunakan terlebih dahulu dinilai oleh validator yang berkompeten dan diujicobakan terhadap responden di sampel. Selanjutnya, dokumentasi untuk pengumpulan data variabel Y yaitu berupa data hasil belajar mahasiswa pada bagian ini dokumen yang dipakai meliputi buku absensi kehadiran, nilai ulangan, nilai tugas, dan nilai ujuan akhir mahasiswa.

Pengujian hipotesis penelitian ini dalam melihat ada atau tidaknnya hubungan antara variabel bebas (kemandirian belajar) dengan variabel terikat (hasil belajar) memakai rumus regresi linear sederhana dengan bantuan aplikasi program komputer SPSS 21.0. Hasil analisis statistik dilakukan dengan membandingkan nilai Sig. product moment dengan $\alpha=0,05$. Kriterianya, jika nilai signifikansi atau probabilitasnya lebih kecil dari 0,05 (Sig. < 0,05) artinya terdapat hubungan. Sebaliknya, jika nilai Signifikansi atau probabilitasnya lebih besar dari 0,05 (Sig. > 0,05) artinya tidak terdapat hubungan/korelasi.

Melihat seberapa erat hubungan/korelasi antara dua variabel dalam penelitian ini dilakukan tahap interpretasi yang berkenaan tentang nilai koefisien korelasi yakni dengan memakai pedoman interpretasi menurut (Sugiyono, 2012:257) sebagai berikut: korelasi sangat rendah $(0,00$ sampai 0,19$)$, korelasi rendah $(0,20$ sampai 0,39$)$, korelasi sedang $(0,40$ sampai 0,59$)$, korelasi kuat $(0,60$ sampai 0,79$)$, korelasi sangat kuat $(0,80$ sampai 1,00$)$.

\section{HASIL DAN PEMBAHASAN}

Hasil analisis statistik deskriptif kemandirian belajar dan hasil belajar mahasiswa pada mata kuliah Matematika-II di MI/SD (Geometri dan Pengukuran) dapat dilihat melalui nilai maksimum, nilai minimum, jumlah nilai, nilai rata-rata, simpangan baku, dan nilai variansnya. Adapun hasilnya dapat diuraikan dengan melihat sajian yang ada pada Tabel 1 berikut:

Tabel 1. Deskripsi Kemandirian Belajar dan Hasil Belajar Descriptive Statistics

\begin{tabular}{lcrrrrrr}
\hline & N & Minimum & Maximum & Sum & Mean & Std. Deviation & Variance \\
\hline $\begin{array}{l}\text { Kemandirian } \\
\text { Belajar }\end{array}$ & 42 & 60,16 & 84,72 & 3189,33 & 75,9364 & 6,10366 & 37,255 \\
\hline Hasil Belajar & 42 & 70,00 & 87,00 & 3297,60 & 78,5143 & 4,59086 & 21,076 \\
\hline $\begin{array}{l}\text { Valid N } \\
\text { (listwise) }\end{array}$ & 42 & & & & & & \\
\hline
\end{tabular}

Berdasarkan Tabel 1, terlihat bahwa variabel kemandirian belajar memperoleh skor minimal 60,16 dan skor maksimal 84,72 dengan skor rata-rata 
75,9364 dan standar deviasi 6,10366 kemudian nilai variansnya sebesar 37,255. Kemudian pada variabel hasil belajar memperoleh skor minimal 70,00 dan skor maksimal 87,00 dengan skor rata-rata 78,5143 dan standar deviasi 4,59086 kemudian nilai variansnya sebesar 21,076.

Selanjutnya dalam menjawab rumusan masalah pada penelitian ini menggunakan analisis statistik inferensial, dimana dalam hal ini memakai regresi linear sederhana dengan rumus korelas pearson product moment. Namun sebelum memulai analisis, hal yang pertama dilakukan yaitu uji normalitas sebagai salah satu syarat dalam analisis statistik inferensial. Adapun perhitungan normalitas memakai uji Kolmogorov-Smirnov untuk kedua variabel dengan memakai aplikasi komputer pada program SPSS 21.0 for windows. Adapun hasil dari perhitungan uji normalitas dapat disediakan pada Tabel 2 serta Gambar 1 berikut ini.

Tabel 2. Hasil Uji Normalitas One-Sample Kolmogorov-Smirnov Test

\begin{tabular}{|c|c|c|}
\hline \multicolumn{3}{|c|}{ Unstandardized Residual } \\
\hline $\mathrm{N}$ & & 42 \\
\hline \multirow{2}{*}{ Normal Parameters ${ }^{a, b}$} & Mean & ,0000000 \\
\hline & Std. Deviation & 2,79874005 \\
\hline \multirow{3}{*}{ Most Extreme Differences } & Absolute & ,075 \\
\hline & Positive & 075 \\
\hline & Negative &,- 060 \\
\hline Kolmogorov-Smirnov Z & & ,488 \\
\hline Asymp. Sig. (2-tailed) & & 971 \\
\hline
\end{tabular}

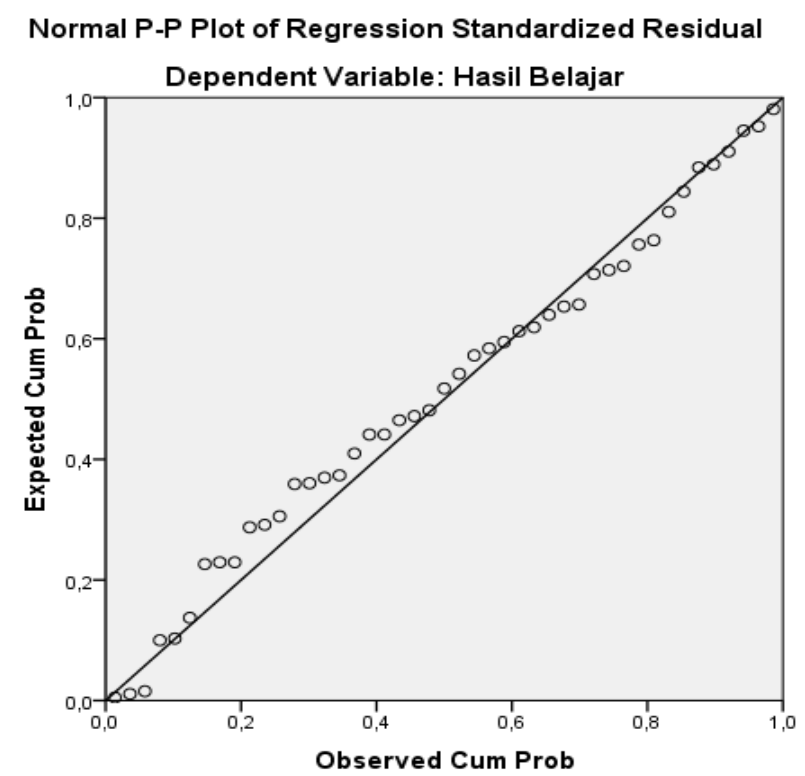

Gambar 1. Hasil Uji Normalitas 
Tabel 2 menunjukkan bahwa data pada kedua variabel mempunyai nilai sig. $(=0,971)$ lebih besar dari nilai $\alpha(=0,05)$ sehingga dapat disimpulkan data tersebut berdistribusi normal. Kemudian hasil tersebut diperkuat oleh Gambar 1 menunjukkan bahwa titik-titik nilai data terletak berdekatan pada satu garis diagonal. Berdasarkan Tabel 2 dan Gambar 1, maka dapat diambil keputusan bahwa kedua variabel penelitian ini berasal dari populasi yang berdistribusi normal. Artinya syarat dalam uji statistik inferensial data telah terpenuhi yaitu data sampel berdistribusi normal.

Tahap analisis regresi linear sederhana dari data angket dan hasil belajat menggunakan uji korelas pearson product moment pada kedua variabel penelitian dengan memakai bantuan program software SPSS 21.0 for windows. Tabel 3 berikut ini adalah hasil perhitungan korelasi pearson product moment.

Tabel 3. Hasil Uji Korelasi Pearson

\begin{tabular}{|c|c|c|c|}
\hline & & $\begin{array}{l}\text { Kemandirian } \\
\text { Belajar }\end{array}$ & Hasil Belajar \\
\hline \multirow{3}{*}{ Kemandirian Belajar } & Pearson Correlation & 1 &, $793^{* \prime}$ \\
\hline & Sig. (2-tailed) & & ,000 \\
\hline & $\mathrm{N}$ & 42 & 42 \\
\hline \multirow{3}{*}{ Hasil Belajar } & Pearson Correlation &, $793^{* \pi}$ & 1 \\
\hline & Sig. (2-tailed) &, 000 & \\
\hline & $\mathrm{N}$ & 42 & 42 \\
\hline
\end{tabular}

Berdasarkan Tabel 3 hasil output uji korelasi Pearson diperoleh bahwa angka signifikansi untuk hubungan kemandirian belajar dengan hasil belajar adalah sebesar 0,000. Artinya nilai Sig. $(=0,000)<\propto(=0,05)$ sehingga cukup bukti untuk mengambil keputusan bahwa terdapat hubungan yang signifikan antara kemandirian belajar (Variabel $\mathrm{X}$ ) dengan hasil belajar mahasiswa matakuliah Matematika-II di MI/SD (Variabel Y).

Melihat kekuatan ataupun keeratan hubungan antara kemandirian belajar (variabel X) dengan hasil belajar matakuliah Matematika-II di MI/SD (variabel Y) dapat diperhatikan dari Tabel 4 pada bagian Pearson Correlation sebesar 0,793 kemudian dikaitkan dengan interpretasi nilai $r$ yang tertera pada Tabel 1. Oleh karena Pearson Correlation sebesar 0,793 berada pada interpretasi nilai $r$ berkorelasi kuat, maka taraf keeratan ataupun kekuatan hubungan kedua variabel dikategorikan kuat. Dengan demikian diperoleh keputusan bahwa terdapat hubungan kuat ke arah positif antara variabel kemandirian belajar dengan variabel hasil belajar mahasiswa matakuliah Matematika-II di MI/SD. Korelasi tersebut dapat dimaknai bahwa jika kemandirian belajar siswa semakin tinggi maka semakin tinggi pula hasil belajar yang diperolehnya pada matakuliah Matematika- 
II.

Hasil riset ini selaras dengan hasil penelitian terdahulu yang dilaksanakan dengan konteks yang berbeda di negara maju seperti China yaitu penelitian dari (Peng, 2012) yang menyelidiki hubungan antara kemandirian belajar dengan prestasi akademik. Sebuah sampel dari 101 mahasiswa dari Jilin Normal University. Temuannya menunjukkan bahwa kemandirian belajar, strategi kognitif, dan kecemasan adalah prediktor penting dari prestasi akademik. Hasil penelitian tersebut relevan dengan penelitian (Kosnin, 2007:226) dimana hasil penelitiannya menyimpulkan bahwa kemandirian belajar bisa menjelaskan besaran IPK mahasiswa. Secara tidak langsung penelitian ini menjelaskan bahwa prestasi akademik dapat diprediksi dengan melihat kemandirian belajar mahasiswa dalam belajar.

Penelitian ini juga sejalan dengan riset yang dilakukan oleh peneliti dalam negri yaitu (Kulsum, U., 2017:4) dimana dalam pembahasan hasil penelitiannya menjelaskan bahwa ada korelasi yang signifikan antara kemandirian belajar dalam kursus dibidang tekstil melalui model pembelajaran Hybrid terhadap hasil belajar. Badrulaini (2018:854) juga melakukan penelitian yang hampir sama di SMA Babussalam Pekanbaru dimana hasil yang diperoleh ialah terdapat korelasi atau keterkaitan yang cukup signifikan antara kemampuan pemecahan masalah dan kemandirian belajar terhadap hasil belajar siswa pada pelajaran matematika. Beberapa kajian terdahulu tersebut menandakan bahwa jika seseorang mempunyai kemandirian belajar yang tinggi, maka dia akan memperoleh hasil belajar yang tinggi juga. Hal ini dapat diambil hubungan korelasi bahwa jika kemandirian belajar seseorang meningkat maka hasil belajarnya juga akan meningkat.

Penjelasan diatas secara tidak langsung juga membuktikan kutipan atau kata-kata bijak yang akhir-akhir ini sering tersebar di sosial media yaitu "usaha tidak akan mengkhianati hasil", maknanya tidak jauh berbeda dengan kemandirian belajar baik tidak akan mengkhianati hasil belajar. Artinya, peserta didik yang mempunyai sifat kemandirian belajar yang kuat pasti memiliki inisiatif belajar yang baik dan mampu menetapkan target belajar. Sikap kemandirian dapat ditunjukkan dengan mampu mengatur diri sendiri artinya dia berdaulat atas dirinya sendiri dan memiliki kemampuan menyelesaikan masalah dengan kepercayaan terhadap kemampuannya sendiri secara sadar. Dengan adanya kemandirian belajar siswa tersebut sudah jelas bahwa kemandirian belajar dapat mengantarkan anak didik memperoleh hasil belajar yang tinggi.

Namun, adapula ditemui hasil kemandirian belajarnya rendah tapi dalam hal ini hasil belajar matematikanya memperoleh nilai yang tinggi. Keadaan tersebut mungkin bisa saja terjadi, sebab ada beberapa aspek lain yang menyebabkan dia mendapatkan hasil belajar yang tinggi yaitu: pada saat tes mahasiswa tidak jujur dan diasumsikan melakukan kecurangan dengan menyontek atau menyalin jawaban temannya ketika ujian sehingga kemandirian belajarnya pun rendah 
karena tidak mempercayai kemampuan sendiri dan dia menjadi ketergantungan kepada temannya. Terlepas dari keadaan diatas, kemandirian belajar memang bukan satu-satunya aspek yang menentukan hasil belajar peserta didik meningkat. Tetapi ada aspek lain yang bisa memengaruhi tinggi ataupun rendahnya hasil belajar mahasiswa baik itu bersumber dari dalam maupun dari luar seperti kurikulum, dukungan dari orang sekitar, sarana dan prasarana berupa media dan bahan ajar, kedisiplinan, lingkungan sekolah termasuk guru, lingkungan keluarga, lingkungan masyarakat, model dan metode pembelajaran yang digunakan dan lain sebagainya yang memiliki potensi mempengaruhi peserta didik dalam belajar.

Mengingat bahwa ada aspek lain yang juga ikut mempengaruhi hasil belajar mahasiswa salah satunya adalah kurikulum, maka pemerintah yang berwenang memberikan kebijakan agar setiap perguruan tinggi harus mengimplementasikan kurikulum berbasis KKNI. kurikulum KKNI ini memang sudah berlangsung dari dua tahun terakhir. Kurikulum berbasis KKNI ini memang sangat dibutuhkan di perguruan tinggi karena kurikulum tersebut dapat mengasah kemampuan dan keahlian mahasiswa dengan mewajibkan mahasiswa melakukan segala aktivitas ataupun kegiatan belajar secara mandiri. Perkuliahan yang menerapkan kurikulum KKNI lebih menuntut kemandirian mahasiswa untuk berinovasi dalam belajar, mencari referensi ataupun bahan kuliah yang lebih beragam, melakukan riset sederhana, dan menggali ilmu yang lebih bermakna. Intinya kurikulum tersebut mewajibkan adanya sifat kemandirian belajar pada tiap-tiap mahasiswa. Oleh karena itu, keadaan tersebut lagi-lagi menandakan bahwa bagian yang cukup penting dan harus dimiliki oleh peserta didik adalah kemandirian belajar.

\section{KESIMPULAN}

Hasil uji korelasi pada riset ini menjelaskan bahwa terdapat korelasi atau hubungan yang kuat ke arah positif antara kemandirian belajar dengan perolehan hasil belajar mahasiswa matakuliah Matematika-II di MI/SD. Berlandaskan pada output uji korelasi dalam penelitian tersebut dapat kita simpulkan bahwa kemandirian belajar sangat kuat kaitannya dengan hasil belajarnya. Maknanya adalah semakin tinggi kadar kemandirian seseorang dalam belajar maka cenderung makin tinggi pula perolehan hasil belajarnya, begitu juga sebaliknya. Mahasiswa yang memiliki kemandirian belajar pasti lebih mudah memahami materi dan ditambah dukungan fasilitas belajar, sehingga kedua faktor tersebut juga memengaruhi pencapaian hasil belajar tinggi.

Kemandirian belajar menekankan pada belajar itu sebagai rangkaian kegiatan dimana peserta didik berpikir, mengalami proses dan bertindak sesuai keinginan mereka sendiri untuk menggapai tujuan belajar mereka. Dalam proses ini, peserta didik menerapkan strategi apa yang cocok mereka gunakan untuk memilih, menggunakan, memantau dan menyesuaikan strategi pembelajaran dan 
menerapkan strategi untuk mengendalikan tindakan guna mencapai tujuan pembelajaran yang spesifik. Jadi, proses ini melibatkan motivasi belajar peserta didik, penetapan tujuan, pengendalian tindakan dan strategi pembelajaran. Intinya, peserta didik yang mandiri tentu tidak akan merugi karena dia memiliki sifat progresif, ulet, mandiri, inofatif, kreatif, inisiatif, yakin pada kemampuan diri, dan mampu mengatasi masalahnya sendiri dengan penuh tanggung jawab sehingga pada akhirnya peserta didik akan mencapai hasil belajar yang maksimal.

\section{DAFTAR PUSTAKA}

Alotaibi, Tohmaz, and J. (2017). The Relationship Between Self-Regulated Learning and Academic Achievement for a Sample of Community College Students at King Saud University. Education Journal, 6(1), 28-37.

Arikunto, S. (2005). Dasar-Dasar Evaluasi Pendidikan (Edisi Revisi) Cetakan ke5. Jakarta: Bumi Aksara.

Badrulaini. (2018). Hubungan Kemampuan Pemecahan Masalah dan Kemandirian Belajar Terhadap Hasil Belajar Matematika Peserta Didik. Jurnal Pendidikan Tambusai, 2(4).

Çam, S. S., and Oruç, E. Ü. (2014). Learning Responsibility and Balance of Power. International Journal of Instruction, 7(1), 5-16.

Cheng, E. C. K. (2011). The Role of Self-Regulated Learning in Enhancing Learning Performancee. The International Journal of Research and Review, $6(1)$.

Dabbagh, N., and Kitsantas, A. (2012). Personal Learning Environments, Social Media, and Self-Regulated Learning: A Natural Formula for Connecting Formal and Informal Learning. Internet and Higher Education, 15, 3-8.

Fauzi, A., and Widjajanti, D. B. (2018). Self-regulated learning: the effect on student's mathematics achievement. IOP Conf. Series: Journal of Physics: Conf. Series 1097(2018) 012139. https://doi.org/10.1088/1742$6596 / 1097 / 1 / 012139$

Kosnin, A. (2007). Self-regulated learning and academic achievement in Malaysian undergraduates. International Education Journal, ISSN 14431475, 8(1), 221-228.

Kulsum, U., D. (2017). Improvement of Learning Independence and Learning Outcomes on Textile Course through Hybrid Learning Model. IOSR Journal Of Humanities and Social Science (IOSR-JHSS), 22(8), 1-5.

Muhammad, A. S., \& Abu Bakar, N. (2015). Relationship of self-regulated learning and academic achievement among universiti sultan zainalabidin 
(UNISZA) undergraduate students. In International Conference on Empowering Islamic Civilization in the 21st Century. Universiti Sultan Zainal Abidin, Malaysia.

Pange, J. (2014). Self regulated learning Strategies in Groups of Learners. University of Ioannina (Greece) ISSN 1392-3137, TILTAI(1).

Peng, C. (2012). Self- regulated learning behavior of college students of science and their academic achievement. Physics Procedia, 33, 1446-1450.

Pintrich, P. (1995). Understanding Self-Regulated Learning. In P. Pintrich (Ed.), Understanding Self-Regulated Learning. San Francisco, CA: Jossey-Bass.

Qohar, A., and S. U. (2013). Improving Mathematical Communication Ability and Self Regulation Learning of Yunior High Students by Using Reciprocal Teaching. Jurnal IndoMS. J.M.E, 4(1), 59-74.

Sudjana, N. (2009). Penilaian Hasil Proses Belajar Mengajar. Bandung: PT Remaja Rosdakarya.

Sugiyono. (2012). Metode Penelitian Pendidikan, Pendekatan Kuantitatif, Kualitatif, dan $R \& D$. Bandung: Alfabeta.

Sumarmo, U. (2004). Kemandirian Belajar Apa, Mengapa dan Bagaimana dikembangkan pada Peserta Didik. In Makalah disajikan pada Seminar Pendidikan Matematika di FMIPA Universitas Negeri Yogyakarta. 